\title{
Occupational Health Development in the Army
}

\author{
JP Owen
}

\begin{abstract}
Occupational Health $(\mathrm{OH})$ in the Army is provided as part of an integrated primary healthcare service. When compared to the International Labour Organisation criteria for the provision of $\mathrm{OH}$, it can be seen that the Army provides all of the $\mathrm{OH}$ elements expected in a large national organisation. However, there is a need to enhance the clinical element of the service and to provide a focus for implementing $\mathrm{OH}$ policy at unit level. The use of qualified $\mathrm{OH}$ nurses based at GP group practices and providing a visiting service to units would rectify this balance as this would enable workplace assessments to be carried out on a regular basis, enhance the ability to carry out occupational health assessments and facilitate health surveillance data collection. The result would be the improved delivery of $\mathrm{OH}$ services to Army personnel, thus helping to maximise the number of soldiers and officers fit to carry out their military duties.
\end{abstract}

\section{Introduction}

Despite great advances in modern technology, arguably the most important element of the fighting machine - the human - has remained essentially unchanged from the first time that Armies were formed. In order to ensure that the human component works to his or her best capacity there has to be a significant investment in support services. As with mechanical systems, the best way to ensure that the human component of the fighting machine functions optimally is by implementing suitable preventive, monitoring and servicing strategies, thus minimising the chances of breakdown. This requires a multidisciplinary approach from several different agencies, including the health services.

Occupational Health $(\mathrm{OH})$ is the branch of the health services concerned with the inter-relationships between work, health and ill health. This includes the effect that a worker's (ill)health can have on his or her ability to carry out work and the way that the work environment can affect his or her health. In order to ensure that soldiers can work and fight to their optimal capacity there must be appropriate $\mathrm{OH}$ support enable them to carry out their dutie unimpeded by illness or injury. This pape will explore the way in which the Ofl services are provided to Army personnew using external criteria as a benchmark. It will also suggest a future model fœ improving the delivery of that services through the employment of $\mathrm{OH}$ traine nurses working within Primary Care supporting the GPs and providing a link to the other $\mathrm{OH}$ specialists.

\section{The Role Of Occupational Health Services}

In 1950 a joint International Laboug Organisation (ILO)/World Healt⿳⺈ Organisation committee defined the purpose of an occupational health service being "to promote and maintain the physica? mental and social wellbeing of all staff" (1 This highlighted the importance of maintaining health and acknowledged th multidisciplinary approach that is require to provide a complete $\mathrm{OH}$ service.

In order to provide such an $\mathrm{OH}$ servic the ILO also identified the types of activitie that should be provided by large national 函 multinational organisations(2), which are summarised in the first two columns 产. Table 1. These include the surveillance individual workers by means of pre employment and periodic in-service healt assessments to enable the systemati identification of at-risk groups. This als requires risk assessments of the workplace्g to be carried out to identify and quantif the biological, chemical, physical ang ergonomic hazards present. $\mathrm{OH}$ expertise should also be provided in planning futuro working environments to ensure that healt risks are minimised. Large organisations should also ensure that suitable first aid an: treatment services are available for then workforce. Whilst there has been a steadF move towards preventive rather that treatment services, the latter remain important in those countries where $\overrightarrow{\vec{q}}$ suitable national healthcare service is no widely accessible. In all environments ther is also a role for education and healt增 promotion to continually work towards improving the health of the workforce.

Over the last 15 years since the IL@ criteria were published additional roles fof. $\mathrm{OH}$ professionals have developed in areas 
Table 1. ILO recommended $\mathrm{OH}$ Services for large national/international organisations

\begin{tabular}{|c|c|c|}
\hline & $\begin{array}{l}\text { Method of Implementation in } \\
\text { National/International Organisations }\end{array}$ & $\begin{array}{l}\text { Method of Implementation in } \\
\text { the Army Medical Services }\end{array}$ \\
\hline $\begin{array}{l}\text { Surveillance of the individual worker's } \\
\text { health in relation to work. }\end{array}$ & $\begin{array}{l}\text { - Pre-employment health examination. } \\
\text { - Periodic health examination. } \\
\text { - Specific examination of selected groups } \\
\text { of workers. }\end{array}$ & $\begin{array}{l}\text { - PULHHEEMS System (Pre- } \\
\text { Service, In-Service, Release } \\
\text { examinations) } \\
\text { - Medical Boarding System } \\
\text { - Special Medical Examinations }\end{array}$ \\
\hline $\begin{array}{l}\text { Provision of curative services for } \\
\text { occupational diseases/accidents. }\end{array}$ & $\begin{array}{l}\text { - Diagnosis and treatment of } \\
\text { occupational diseases. } \\
\text { - Treatment and first aid for } \\
\text { occupational diseases. }\end{array}$ & $\begin{array}{l}\text { - Primary Health Care Service } \\
\text { - Occupational Medicine (OM) } \\
\text { specialists at Formation Level } \\
\text { - Defence Secondary Care Agency } \\
\text { (DSCA) }\end{array}$ \\
\hline Provision of general healthcare services. & $\begin{array}{l}\text { - Diagnosis and treatment of non- } \\
\text { occupational diseases. } \\
\text { - Vaccination of employees. }\end{array}$ & $\begin{array}{l}\text { - Primary Health Care Service } \\
\text { - DSCA }\end{array}$ \\
\hline Securing future working environment. & $\begin{array}{l}\text { - Strategies for occupational health } \\
\text { programmes. } \\
\text { - The planning of new or changed } \\
\text { workstations / practices / work organisation. }\end{array}$ & $\begin{array}{l}\text { - Specialist medical staff advice } \\
\text { to commanders at all levels } \\
\text { - Environmental Health Team } \\
\text { (EHT) support }\end{array}$ \\
\hline $\begin{array}{l}\text { Surveillance of the current working } \\
\text { environment. }\end{array}$ & $\begin{array}{l}\text { - Walk-through surveys with } \\
\text { guidance checklists. } \\
\text { - Risk assessment of chemical / physical / } \\
\text { ergonomic hazards. } \\
\text { - Psychological / psychosocial assessments. }\end{array}$ & $\begin{array}{l}\text { - Regimental Medical Staff } \\
\text { - EHT } \\
\text { - Health and Safety (H\&S) Officers } \\
\text { - OM staff (Formation and } \\
\text { Command level) }\end{array}$ \\
\hline Advice on the control of hazards at work. & $\begin{array}{l}\text { - Ergonomic / climate / dust exposure / } \\
\text { chemical hazards / noise. } \\
\text { - Personal protective equipment (PPE). }\end{array}$ & $\begin{array}{l}\text { - EHT } \\
\text { - OM staff (Formation and } \\
\text { Command level) } \\
\text { - H\&S Officers }\end{array}$ \\
\hline Health education and health promotion. & $\begin{array}{l}\text { - General health information to } \\
\text { the workers. } \\
\text { - Information about healthy lifestyle / } \\
\text { health promotion. } \\
\text { - Information / training in first aid. }\end{array}$ & $\begin{array}{l}\text { - Primary Health Care } \\
\text { - Health Promotion staff, } \\
\text { where available }\end{array}$ \\
\hline
\end{tabular}

concerned with rehabilitation, epidemiology and legislation. As modern organisations work with very lean manning margins, there is an increasing need to get staff back to work as soon as possible following illness or injury, which has resulted in greater demands for suitable rehabilitation facilities. An increased requirement to be able to demonstrate evidence based practices has also resulted in a marked rise in the demand for data on individual employees and their workplace, requiring specialist epidemiological skills to provide meaningful interpretation to that information. Increasingly complex health and safety legislation in the workplace also requires specialist $\mathrm{OH}$ advice and support to provide a defence against an increased readiness of both employees and public to resort to litigation at an early stage.

In order to provide such a wide range of services, $\mathrm{OH}$ teams have to be multidisciplinary. The past emphasis on doctor-based treatment services has been replaced by $\mathrm{OH}$ professionals working together in truly multidisciplinary teams involving the following: doctors, nurses, occupational hygienists, toxicologists, ergonomists, social workers, psychologists, epidemiologists, safety officers and lawyers. No single organisation can sustain such a
Table 2. Individual and Organisational Benefits Provided by $\mathrm{OH}$ Services

- Ensuring individuals are 'fit for work'.

- Decreased sickness absence, through management of long term sickness and overseeing occupational rehabilitation.

Improved workforce motivation.

- Improved productivity

- Improved efficiency.

Decreased staff turnover and operating costs.

- Legal compliance.

- Decreased risk of costly litigation.

- Improved risk management.

wide range of staff, therefore, a core $\mathrm{OH}$ team of doctors, nurses and possibly occupational hygienists is usually maintained, with access to the more $\tilde{N}^{\circ}$ specialised services on a contractual basis.

Whilst accepting the intellectual argument for providing $\mathrm{OH}$ support for their workforce, most organisations require 0 more tangible evidence of the benefits of investing in $\mathrm{OH}$ services. This evidence can be difficult to measure directly, though the benefits of promoting and maintaining a healthy workforce can be demonstrated for $\stackrel{\mathbb{D}}{2}$ both the organisation, and the individual, in a number of ways as shown in Table 2 . These factors all add up to greatly improved cost effectiveness of the organisation. 


\section{OH Provision In The Army}

It is clear that the ILO/WHO definition of the purpose of an $\mathrm{OH}$ service is also valid for the Army, where personnel have to be physically and psychologically 'fit' and capable of deploying on military operations worldwide, often at short notice.

If the services provided by the Army Medical Services (AMS) are compared to the criteria set by the ILO it can be seen that all of the areas are covered, at least in part and in many cases are exceeded, as shown in the third column of Table 1. In common with the other two Services, the Army provides an $\mathrm{OH}$ service that is integrated into the Primary Health Care service. The bulk of $\mathrm{OH}$ care is provided within medical centres using doctors, nurses and combat medical technicians. This includes provision of treatment services for occupational and general conditions, routine work related health surveillance, health education and health promotion. It is only when complex cases are encountered or certain specific assessments are required that specialist $\mathrm{OH}$ staff may have to be consulted.

The surveillance of the current working environment is one area of $\mathrm{OH}$ provision in the Army that has traditionally relied largely on regimental medical staff, especially the Regimental Medical Officer (RMO), who is the Commanding Officer's medical adviser. However, the increasing use of Group Practices and the demands of specialist training as GP Specialist Registrars has resulted in many RMOs spending significantly less time within their units, reducing the opportunity for them to carry out basic workplace assessments. The basic $\mathrm{OH}$ provision is further degraded through the reliance, in many locations, on sessional

Table 3. Potential Army OH Nursing Roles Within Primary Care

\begin{tabular}{|c|c|}
\hline OH Services & $\begin{array}{l}\text { Potential OH Nurse Roles } \\
\text { within Army Primary Care }\end{array}$ \\
\hline $\begin{array}{l}\text { Surveillance of the individual } \\
\text { worker's health in relation to work }\end{array}$ & $\begin{array}{l}\text { - Carrying out routine In-Service } \\
\text { PULHHEEMS } \\
\text { - Initial assessment of personnel } \\
\text { presenting with work related disorders }\end{array}$ \\
\hline Provision of general healthcare services & $\begin{array}{l}\text { - Coordinating immunisation } \\
\text { programmes }\end{array}$ \\
\hline Securing future working environment & $\begin{array}{l}\text { - Providing specialist } \mathrm{OH} \text { advice } \\
\text { to COs }\end{array}$ \\
\hline $\begin{array}{l}\text { Surveillance of the current working } \\
\text { environment }\end{array}$ & $\begin{array}{l}\text { - Carrying out workplace assessments } \\
\text { - Coordinating Health Surveillance } \\
\text { programmes (Morbidity surveillance, } \\
\text { Audiometry, Respiratory Function } \\
\text { Testing, Skin assessments) }\end{array}$ \\
\hline Advice on the control of hazards at work & $\begin{array}{l}\text { - Providing advice to Unit COSHH } \\
\text { officers }\end{array}$ \\
\hline Health education and health promotion & $\begin{array}{l}\text { - Hearing Conservation, Manual } \\
\text { Handling, Occupational Stress } \\
\text { Management }\end{array}$ \\
\hline $\begin{array}{l}\text { Management of long term sickness } \\
\text { absence }\end{array}$ & $\begin{array}{l}\text { - Coordination of support services and } \\
\text { rehabilitation for long term } \\
\text { sick/downgraded personnel }\end{array}$ \\
\hline
\end{tabular}

NHS GPs and civilian medical practitioners who are not contracted to provide $\mathrm{OH}$ support outside the confines of the medica莫 centre.

The Environmental Health teams (EHT) $\stackrel{\mathbb{8}}{\Omega}$ provide a crucial element of the $\mathrm{OH}^{\circ}$ provision down to unit level, being able tơ carry out more specialised workplace? assessments than the regimental medica $\overrightarrow{\vec{S}^{2}}$ staff. The EHT also provide advice on tho control of hazards in the workplace and assist in the planning of future safe working environments in addition to their other non $\mathbb{\Omega}$ $\mathrm{OH}$ related roles. However, they do not have clinical training and, therefore, are limited in the degree of health surveillance they can provide. In addition, as divisiona $\vec{\omega}$ assets, EHTs are often not available to carrt: out routine workplace assessments at unig level.

Both health surveillance and workplace्t assessments are areas of $\mathrm{OH}$ provision tha宅 can be provided by more than one membe $\delta^{\circ}$ of an OH team, though this has yet to b. fully exploited within the Army, where the clinical functions all fall to the MOs witlo EHTs as the only available supporting OFf staff. This presents an unbalanced elemen to the Army OH service, which would b\% rectified by increasing the $\mathrm{OH}$ support thas can be provided down to unit level. $\mathrm{OH}^{-}$ nurses would fill this capability gap being able to carry out workplace assessments an being capable of providing nearly all form of health surveillance, with the fevo exceptions requiring examinations to be carried out by an HSE appointed doctoro Potential roles for $\mathrm{OH}$ nurses in Army $\mathrm{OH}$ are shown in Table 3.

\section{Discussion}

There are a number of advantages is providing an integrated primary healthcar service, which includes General Practice Occupational Medicine, Environment Health and Physiotherapy. Most notable the ability to provide a holistic service fo the patients, with an increased awareness of $\mathrm{OH}$ issues amongst the health professionalo who provide the initial patient contact. truly integrated service will also provide seamless service for patients with the fres flow of relevant information between thio various specialists.

However, in an integrated service there can be difficulties in getting the corree balance between the preventive and the treatment services. With limited resources there is always pressure to focus o $\mathbb{P}^{\circ}$ treatment which has immediate visibility, t两 the detriment of long term benefits accrue of from preventive strategies. The samg resourcing constraints limit the training time and staff availability for $\mathrm{OH}$ relate activities that may not appear to be relevar to core General Practice care.

The emphasis placed on patient 
confidentiality by the GMC (3) has also made it more difficult for GPs in the Army to reconcile their core primary care role with their wider $\mathrm{OH}$ responsibilities. Whilst the principles underpinning the GMC directives are sound, the framework is based on the UK civilian model of having GPs working independently from $\mathrm{OH}$ services and in circumstances where it is possible to differentiate between the two elements of healthcare provision.

It may be that the drive for patient confidentiality and the pressures of service provision placed on Army GPs, compounded by the increasingly specialist training requirements in both General Practice and Occupational Medicine are such that it will be necessary to consider formally separating these two elements of primary care provision. However, whilst taking this route may make it easier to satisfy the civilian model of primary care provision, it would undermine the quality of the total healthcare package provided by the AMS. One of the frequent observations made in civilian $\mathrm{OH}$ services concerns the difficulty in getting useful information flow between the GPs and $\mathrm{OH}$ teams. This can result in patients being placed at increased risk at work because the $\mathrm{OH}$ team have not been made aware of relevant illnesses or conditions which have been reported to the GP. Likewise, patients may have unnecessary investigations or inappropriate treatment because the GP has not been made aware of health issues discovered by the $\mathrm{OH}$ team. It is also very difficult to provide an effective and efficient rehabilitation service unless all of the contributors to the primary care team can work together.

If the integrated approach in the Army is to be maintained, it is suggested that the best way forward is to increase the $\mathrm{OH}$ support to the primary health care teams rather than to become pressurised into separating what are complimentary aspects of military medical care. From examining the way in which the AMS provide the $\mathrm{OH}$ services identified by the ILO/WHO committee, it can be seen that there is little specialist $\mathrm{OH}$ support at unit level. The existing focus for specialist trained $\mathrm{OH}$ staff is at Divisional level and above, concentrating on $\mathrm{OH}$ policy issues. However, in order to ensure that the policies are carried through into practice it is also necessary to have an additional focus on clinical $\mathrm{OH}$ service provision.
$\mathrm{OH}$ provision relies on multidisciplinary $\check{c}^{\complement}$ teams, with the clinical element being $?$ provided by both doctors and nurses. These are frequently nurse-led in civilian practice, $z$ using $\mathrm{OH}$ physicians for referrals when $\stackrel{\mathbb{\alpha}}{\stackrel{\circ}{\circ}}$ required. This is a model that offers a $\varnothing$ suitable level of expertise for first line 음 investigations and surveillance, with further specialist advice available from $\mathrm{OH}$ doctors $\underset{\overrightarrow{\mathrm{g}}}{\mathrm{g}}$ as required.

The requirement for a clinical $\mathrm{OH}$ service, with specialist $\mathrm{OH}$ physicians based on regional medical centres supported by $\stackrel{\varnothing}{\varnothing}$ $\mathrm{OH}$ nursing staff, is one of many issues that $\stackrel{2}{\mathrm{~m}}$ are being considered by the Primary $\overrightarrow{0}$ Healthcare Review team at the Army Medical Directorate. This would ensure $\vec{\omega}$ that $\mathrm{OH}$ policy is implemented and that there is also a suitable route for data collection and the passage of $\mathrm{OH}$ information back to inform the policy making process, thereby enhancing an important element of the audit process.

\section{Conclusions}

The Army provides a range of $\mathrm{OH}$ services within an integrated primary care setting. These services exceed the requirements of the ILO criteria in a number of areas, in addition to providing extra services such as rehabilitation. In order to provide greater coordination of the various elements of $\mathrm{OH}$ services at unit and medical centre level and to assist the GP staff, it is recommended that the clinical component of the $\mathrm{OH}$ service should be enhanced, with particular emphasis on the use of qualified $\mathrm{OH}$ nurses. This would ensure that there is suitable representation of $\mathrm{OH}$ issues down to unit level and that specialist advice can be provided in the workplace. The presence of specialist staff in the workplace would also assist in data collection for audit purposes and provide a means of education for the workforce on $\mathrm{OH}$ issues. The net effect would be an enhanced $\mathrm{OH}$ service to military personnel, whilst still maintaining an integrated approach to primary healthcare.

\section{References}

1. International Labour Organisation/World Health Organisation Joint Committee. Internationa Labour Organisation, 1950.

2. International Labour Organisation. Occupational Health Services Convention and Recommendations, Nos 161 and 171. Geneva International Labour Organisation, 1985.

3. General Medical Council. Protecting Patients, Guiding Doctors. Confidentiality: Protecting and Providing Information. 